\title{
PENGARUH MODEL PEMBELAJARAN COURSE REVIEW HORAY BERBANTUAN MEDIA QUESTION CARD TERHADAP KOMPETENSI PENGETAHUAN IPA
}

\author{
Ni Made Mety Ari Astuti ${ }^{1}$, I Ketut Ardana ${ }^{2}$, Made Putra ${ }^{3}$ \\ 1,2,3 Jurusan Pendidikan Guru Sekolah Dasar, FIP \\ Universitas Pendidikan Ganesha \\ Singaraja, Indonesia \\ email : ni.md.mety.ariastuti@undiksha.ac.id ${ }^{1}$, iketut.ardana@undiksha.ac.id ${ }^{2}$, madeputra@undiksha.ac.id ${ }^{3}$
}

\begin{abstract}
Abstrak
Tujuan penelitian ini untuk mengetahui pengaruh model pembelajaran Course Review Horay berbantuan media Question Card terhadap kompetensi pengetahuan IPA siswa kelas V SD Gugus Pattimura Denpasar Selatan tahun pelajaran 2017/2018. Jenis penelitian ini merupakan eksperimen semu, dengan bentuk non-equivalent control group design. Populasi penelitian ini adalah seluruh kelas $\mathrm{V}$ SD Gugus Pattimura yang terdiri dari 8 kelas dengan banyak siswa 341 orang. Sampel ditentukan dengan teknik random sampling. Sampel penelitian ini adalah kelas VB SDN 7 Sesetan sebagai kelompok eksperimen sebanyak 38 siswa, dan kelas V SDN 18 Sesetan sebagai kelompok kontrol sebanyak 37 siswa. Data kompetensi pengetahuan IPA dikumpulkan dengan instrumen berupa tes objektif pilihan ganda biasa berjumlah 31 butir, tes tersebut telah divalidasi. Data kompetensi pengetahuan IPA dianalisis dengan uji-t. Hasil analisis diperoleh $t_{\text {hitung }}=5,905$. Harga tersebut kemudian dibandingkan dengan harga $t_{\text {tabel }}$ dengan $\mathrm{dk}=73$ dan taraf signifikansi $5 \%$ sehingga diperoleh harga $t_{\text {tabel }}=2,000$, karena $t_{\text {hitung }}>t_{\text {tabel }}$ maka Ho ditolak, yang berarti terdapat perbedaan yang signifikan kompetensi pengetahuan IPA antara kelompok siswa yang dibelajarkan melalui model pembelajaran Course Review Horay berbantuan media Question Card dengan kelompok siswa yang dibelajarkan melalui pembelajaran konvensional pada siswa kelas V SD Gugus Pattimura Denpasar Selatan tahun pelajaran 2017/2018. Sehingga dapat disimpulkan, model pembelajaran Course Review Horay berbantuan media Question Card berpengaruh terhadap kompetensi pengetahuan IPA siswa kelas V SD Gugus Pattimura Denpasar Selatan tahun pelajaran 2017/2018. Disarankan kepada peneliti lain agar penelitian ini dapat digunakan sebagai refrensi untuk melaksanakan penelitian selanjutnya.
\end{abstract}

Kata kunci: course review horay, question card, kompetensi pengetahuan IPA.

Abstract

This study aimed to know the effect of Course Review Horay learning model using Question Card media on knowledge of science competency at fifth students in SD Gugus Pattimura Denpasar Selatan in 2017/2018 academic year. This study was quasi experiment in the form of nonequivalent control group design. The population of this study was all the fifth grade students in SD Gugus Pattimura which consisted of 8 classes with 341 students. The sample was decided by using random sampling technique. The sample of this study was 38 students from VB class in SDN 7 Sesetan as the experimental group while the control group was 37 students from fifth grade class in SDN 18 Sesetan. The science competency data collected by using multiple choices test instrument with 31 items that has been validated. The data analyzed by using T-test. The result of the analysis shows that $t_{\text {count }}=5,905$. That result compares with the result of $t_{\text {table }}$ with $\mathrm{dk}=73$ and the significant standard $5 \%$, the result of $t_{\text {table }}=2,000$, because of $t_{\text {count }}>t_{\text {table }}$ so $H_{0}$ rejected. It means that there was significant different on knowledge of science competency for the students group who taught by using Course Review Horay learning model using Question Card media with the students group who taught by using conventional learning competency fifth grade students in SD Gugus Pattimura Denpasar Selatan at 2017/2018 academic year.It concluded that Course Review Horay learning model using Question Card media gives effect on knowledge of science competency in fifth grade students of SD Gugus Pattimura Denpasar Selatan at 2017/2018 academic year. It is recommended for the other researcher that this study is able to use as a reference for conducting the further research.

Keywords: course review horay, question card, knowledge of science competency. 


\section{Pendahuluan}

Pendidikan merupakan salah satu kebutuhan setiap manusia. Pendidikan mempunyai peranan penting dalam kelangsungan kehidupan manusia, karena melalui pendidikan dapat mengembangkan Sumber Daya Manusia yang lebih berkualitas. Pendidikan adalah "usaha sadar untuk menyiapkan siswa melalui kegiatan bimbingan, pengajaran, dan latihan baik yang dilaksanakan secara formal di sekolah maupun non-formal di luar sekolah" (Sagala, 2012:8). Setiap manusia hendaknya memiliki kesadaran akan pentingnya pendidikan, mengingat masih banyak orang tua yang menganggap pendidikan untuk anaknya sebagai sesuatu yang kurang penting. Oleh karena itu peran serta pemerintah, masyarakat sekitar dan orang tua sangat diperlukan dalam memberikan pendidikan untuk anak dalam mengembangkan potensi dan mencapai kesuksesan. Dalam Pasal 3 Undang-Undang Nomor 20 Tahun 2003 tentang Sistem Pendidikan Nasional disebutkan bahwa pendidikan nasional bertujuan untuk mengembangkan potensi peserta didik agar menjadi manusia yang beriman, berilmu, cakap, kreatif, mandiri, dan menjadi warga negara yang demokratis serta bertanggung jawab.

Sejalan dalam peningkatkan Sumber Daya Manusia yang lebih berkualitas, pendidikan juga terus berkembang ke arah yang lebih baik. Pendidikan tidak terlepas dari adanya kurikulum. Dalam Undang-Undang Nomor 20 Tahun 2003 tentang Sistem Pendidikan Nasional disebutkan bahwa kurikulum adalah seperangkat rencana dan pengaturan mengenai tujuan isi dan bahan pelajaran serta cara yang digunakan sebagai pedoman penyelenggaraan proses pembelajaran untuk mencapai tujuan pendidikan tertentu. Salah satu usaha pemerintah dalam meningkatkan mutu pendidikan adalah dengan adanya perubahan kurikulum sebagai pedoman dalam proses pembelajaran. Kurikulum telah mengalami berbagai perubahan dan penyempurnaan, sejak tahun ajaran 2013/2014 kurikulum yang diterapkan pada jenjang sekolah dasar adalah kurikulum 2013 (Permendikbud Nomor 57 tahun 2014 lampiran 1). Menurut Daryanto dan Sudjendro (2014:17) kurikulum 2013 bertujuan untuk "mempersiapkan insan Indonesia untuk memiliki kemampuan hidup sebagai pribadi dan warganegara yang produktif, kreatif, inovatif, dan afektif serta mampu berkontribusi pada kehidupan bermasyarakat, berbangsa, bernegara dan peradaban dunia".

Pembelajaran pada kurikulum 2013 menggunakan pendekatan saintifik atau pendekatan berbasis proses keilmuan. Pendekatan saintifik dapat menggunakan beberapa strategi seperti pembelajaran kontekstual Menurut Permendikbud, Nomor 103 tahun 2014. Pendekatan saintifik merupakan salah satu cara untuk memberikan pemahaman kepada siswa dalam mengenal, memahami berbagai materi, dan mendorong siswa mencari suatu informasi dari berbagai sumber melalui proses mengamati, menanya, mengumpulkan informasi, menalar/mangasosiasi, dan mengkomunikasi. Melalui pendekatan saintifik diharapkan dapat meningkatkan kompetensi pengetahuan siswa. Salah satunya adalah kompetensi pengetahuan IPA.

Ilmu Pengetahuan Alam atau yang biasa disebut dengan IPA merupakan salah satu muatan materi yang terdapat pada kurikulum 2013 pada jenjang sekolah dasar. IPA adalah "usaha manusia dalam memahami alam semesta melalui pengamatan yang tepat pada sasaran, serta menggunakan prosedur, dan dijelaskan dengan penalaran sehingga mendapatkan suatu kesimpulan" (Susanto, 2013:167). Dengan mempelajari Ilmu Pengetahuan Alam siswa dapat mengetahui tentang makhluk hidup dan alam sekitar yang dekat dengan kehidupan siswa. Selain itu, dengan mempelajari IPA siswa diharapkan mampu menerapkannya dalam kehidupan sehari-hari maupun dalam dunia kerja, oleh karena itu muatan materi IPA di sekolah dasar merupakan salah satu muatan materi yang dianggap sangat penting dan harus dikuasai oleh siswa.

Pada kenyataannya, masih banyak siswa yang belum menguasai muatan materi IPA karena dianggap sebagai muatan materi yang sulit. Hal ini terbukti dari hasil observasi yang dilakukan pada tanggal 11 Januari 2018 dengan guru kelas V dimasing-masing SD Gugus Pattimura Denpasar Selatan tahun pelajaran 2017/2018. Untuk kompetensi pengetahuan pada muatan materi IPA diperoleh dari nilai Ulangan Akhir Semester I yaitu, dari 341 siswa yang belum mencapai Kriteria Ketuntasan Minimal (KKM) yang ditetapkan yakni 70,00 yaitu 219 
siswa atau sekitar $64,22 \%$. Sedangkan, 122 siswa atau sekitar $35,77 \%$ yang sudah mencapai KKM. Berkaitan dengan hal tersebut, setelah dilakukannya observasi diketahui faktor-faktor yang menyebabkan rendahnya hasil kompetensi pengetahuan IPA siswa seperti : a) siswa kurang aktif dalam proses pembelajaran, b) proses pembelajaran pada muatan materi IPA dianggap kurang menarik oleh siswa karena cenderung bersifat hafalan, c) siswa lebih senang mengobrol saat jam pembelajaran berlangsung. Dengan demikian, dipandang perlu adanya peningkatan kompetensi pengetahuan IPA siswa.

Pelaksanaan pembelajaran di kelas perlu dirancang agar lebih menarik dengan memperhatikan karakteristik siswa kelas $\mathrm{V}$ sekolah dasar. Dari permasalahan tersebut dipandang perlu adanya inovasi dalam proses pembelajaran yaitu pembelajaran yang mengutamakan penguasaan kompetensi, berpusat pada siswa, menarik dan menyenangkan serta memberikan pengalaman belajar yang relevan dengan kehidupan nyata. Salah satu inovasi yang dapat diterapkan dalam proses pembelajaran adalah model pembelajaran Course Review Horay.

Model pembelajaran Course Review Horay merupakan model pembelajaran yang dapat menciptakan suasana kelas menjadi meriah dan menyenangkan karena setiap siswa yang dapat menjawab benar maka siswa tersebut diwajibkan berteriak "hore!" atau yel-yel lainnya yang disepakati. Pembelajaran Course Review Horay merupakan salah satu pembelajaran kooperatif yang dilakukan dengan mengelompokkan siswa ke dalam kelompok-kelompok kecil (Kurniasih dan Berlin, 2015:80). Dengan menerapkan model pembelajaran Course Review Horay siswa dapat berperan aktif dalam proses pembelajaran. Karena dalam proses pembelajaran, siswa diwajibkan berpartisipasi secara aktif dalam menjawab pertanyaan. Secara tidak langsung penerapan model pembelajaran Course Review Horay dalam proses pembelajaran akan melatih pemahaman siswa terhadap materi pembelajaran. Selain itu, proses pembelajaran menjadi lebih menarik dan menyenangkan dengan mewajibkan siswa berteriak "Hore!" atau menyanyikan yel-yel kelompoknya saat berhasil menjawab pertanyaan yang diberikan oleh guru dengan benar. Dengan menggunakan model pembelajaran Course Review Horay diharapkan dapat membuat pembelajaran pada muatan materi IPA menjadi lebih menyenangkan dan nilai pada kompetensi pengetahuan IPA dapat meningkat.

Penggunaan media pembelajaran juga mempunyai peranan penting dalam menentukan keberhasilan proses pembelajaran di sekolah dasar. Media pembelajaran merupakan salah satu komponen yang memiliki peranan penting dalam menunjang proses pembelajaran serta mempermudah penyampaian materi atau konsep kepada siswa. Salah satu media pembelajaran yang dapat menunjang proses pembelajaran dengan menggunakan model pembelajaran Course Review Horay adalah media Question Card. Media pembelajaran Question Card atau kartu soal merupakan salah satu jenis media pembelajaran visual. Media pembelajaran Question Card atau kartu soal merupakan media visual yang berupa kertas berukuran $10 \times 10 \mathrm{~cm}$, isi dari kartu ini adalah soal-soal yang berkaitan dengan materi pelajaran yang dibahas (Ardani, 2014). Dengan menggunakan media Question Card pelaksanaan proses pembelajaran menjadi lebih menyenangkan bagi siswa. Serta siswa diharapkan dapat menumbuhkan rasa tanggung jawab, kerjasama, dan aktif dalam menyalurkan pendapatnya.

Berdasarkan latar belakang masalah yang telah diuraikan, maka dilaksanakan penelitian yang berjudul "Pengaruh Model Pembelajaran Course Review Horay Berbantuan Media Question Card Terhadap Kompetensi Pengetahuan IPA Siswa Kelas V SD Gugus Pattimura Denpasar Selatan Tahun Pelajaran 2017/2018".

\section{Metode}

Penelitian ini dilaksanakan pada semester 2 tahun pelajaran 2017/2018 di kelas V SD Gugus Pattimura Denpasar Selatan. Jenis penelitian yang digunakan adalah penelitian kuantitatif yaitu penelitian eksperimen dengan desain eksperimen semu (quasy experimental design).Bentuk desain eksperimen semu yang digunakan dalam penelitian ini yaitu nonequivalent control group design. Dalam desain ini terdapat dua kelompok sampel yang terdiri 
dari kelompok eksperimen dan kelompok kontrol sebagai subjek penelitian yang akan dibandingkan. Rancangan ini menggunakan pre test sebagai penyetaraan kelompok. Secara skematis, desain eksperimen semu (quasy experimental design) yang digunakan pada penelitian ini dapat diilustrasikan sebagai berikut.

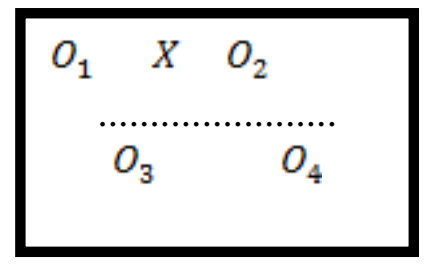

(Sumber: Sugiyono, 2017:79)

Keterangan :

\section{Gambar Non-Equivalent Control Group Design}

O1 =pre test pada kelompok eksperimen

O2 =post test pada kelompok eksperimen

$\mathrm{O} 3=$ pre test pada kelompok kontrol

$\mathrm{O} 4=$ post test pada kelompok kontrol

$\mathrm{X}=$ perlakuan (treatment) dengan menggunakan model pembelajaranCourse Review Horay berbantuan media Question Card pada kelompok eksperimen

Teknik yang digunakan dalam penyetaraan kelompok adalah dengan menggunakan ujit. Setelah itu diberikan perlakuan, yaitu dengan memberikan model pembelajaran Course Review Horay berbantuan media Question Card kepada kelompok eksperimen dan memberikan pembelajaran konvensional kepada kelompok kontrol. Kemudian setelah diberikan perlakuan, dilakukan post test untuk mengetahui kompetensi pengetahuan IPA.

Populasi dari penelitian ini adalah seluruh siswa kelas V SD Gugus Pattimura Denpasar Selatan tahun pelajaran 2017/2018, yang terdiri dari 8 kelas dalam 5 sekolah dasar yang berjumlah 341 siswa.Setelah mengetahui populasi, langkah selanjutnya adalah menentukan sampel penelitian. Teknik pengambilan sampel pada penelitian ini adalah Random Samplingsehingga setiap kelas mendapatkan peluang yang sama untuk menjadi sampel penelitian. Pemilihan sampel penelitian ini tidak dilakukan pengacakan individu melainkan hanya pengacakan kelas. Untuk menentukan sampel dalam penelitian ini, cara yang digunakan adalah dengan cara pengundian.

Hasil dari pengundian diperoleh dua kelas yang dijadikan sampel penelitian, yaitu kelas VB SD Negeri 7 Sesetan dan kelas V SD Negeri 18 Sesetan. Setelah itu, dua kelas hasil pengundian diberikan pre test, kemudian nilai dari hasil pre testdigunakan untuk penyetaraan kelas sampel. Untuk penyetaraan kelas sampel, nilai dari hasil pre test dianalisis menggunakan uji-t. Sebelum uji kesetaraan menggunakan uji-t, data hasil pre test diuji prasyarat yaitu uji normalitas sebaran data dan uji homogenitas varians.Setelah diketahui kedua kelompok sampel setara, kemudian dilakukan pengundian yang kedua untuk menentukan kelas eksperimen dan kelas kontrol. Setelah dilakukan pengundian, kelas yang terpilih untuk menjadi kelas eksperimen adalah kelas VB di SD Negeri 7 Sesetan dan untuk kelas kontrol terpilih kelas V di SD Negeri 18 Sesetan.

Data yang dikumpulkan dalam penelitian ini adalah data kompetensi pengetahuan IPA siswa kelas V di SD Gugus Pattimura Denpasar Selatan tahun pelajaran 2017/2018. Metode pengumpulan data yang digunakan dalam penelitian ini adalah dengan metode tes. Tes yang akan digunakan untuk mengukur kompetensi pengetahuan IPA siswa kelas $\mathrm{V}$ berupa tes objektif dalam bentuk pilihan ganda biasa.

Tes objektif pilihan ganda biasa yang digunakan dalam penelitian ini terdiri dari 40 butir soal. Dalam tes ini dilakukan pengujian instrumen yaitu uji validitas, daya beda, tingkat kesukaran, dan reliabilitas. 
Validitas yang digunakan dalam penelitian ini yaitu validitas isi dan validitas butir. Uji validitas isi dalam penelitian ini adalah menyusun instrumen berdasarkan kisi-kisi yang merujuk pada kurikulum. Pengujian validitas isi instrumen penelitian ini dilakukan dengan melibatkan pendapat pakar/ahli. Untuk itu, dalam penyusunan tes penguasaan kompetensi pengetahuan IPA dilakukan konsultasi dengan dosen pada mata kuliah IPA dan guru kelas.

Untuk mengukur validitas butir teskompetensi pengetahuan IPA dalam bentuk objektif pilihan ganda digunakan rumus koofesien korelasi point biserial $\left(r_{\text {pbi }}\right)$ karena tes yang digunakan bersifat dikotomi.Nilai yang diperoleh kemudian dibandingkan dengan nilai yang diperoleh dari $r_{\text {tabel }}$, dengan taraf signifikansi sebesar $5 \%$, jika $r_{\text {hitung }}>r_{\text {tabel, }}$, berarti instrumen dinyatakan valid dan jika $r_{\text {hitung }} \leq r_{\text {tabel}}$, berarti instrumen dinyatakan tidak valid.Dari hasil perhitungan dengan $r_{\text {tabel }}$ pada taraf signifikansi 0,05 yaitu 0,344 terdapat 9 soal yang kurang dari $r_{\text {tabel }}(0,344)$ atau tidak valid dan 31 butir soal yang lebih dari $r_{\text {tabel }}(0,344)$ atau valid. Soal yang dinyatakan valid kemudian dilanjutkan diuji dengan uji daya beda.

Daya beda butir tes ialah kemampuan butir tes tersebut membedakan antara testee kelompok atas (pintar) dan testee kelompok bawah (lemah). Untuk menentukan kelompok atas dan kelompok bawah adalah dengan mengambil masing-masing 50\% dari jumlah sampel untuk kelompok atas dan kelompok bawah.Indeks daya beda yang digunakan untuk tes dalam penelitian ini adalah dari 0,4 sampai 1,00 dalam kategori cukup, baik dan baik sekali.Berdasarkan hasil pengujian, soal yang memiliki daya pembeda cukup yaitu sebanyak 17 butir soal, soal yang memiliki daya pembeda baik yaitu sebanyak 13 butir soal dan baik sekali sebanyak 1 butir soal dari 31 soal yang valid.

Soal yang telah diuji validitas butir tes dan uji daya beda kemudian diuji tingkat kesukaran butir tes. Hasil uji tingkat kesukaran butir tes menunjukkan bahwa soal sukar sebanyak 5 butir, soal sedang sebanyak 21 butir, dan soal mudah sebanyak 5 soal dari 31 soal. Sedangkan tingkat kesukaran perangkat tes yang digunakan yaitu 0,57 yang berada pada kriteria sedang.

Uji reliabilitas dilakukan hanya pada butir soal yang telah diuji validitas butir tes dan dinyatakan valid. Tes dalam penelitian ini bersifat dikotomi sehingga rumus yang digunakan untuk uji reliabilitas tes adalah rumus Kuder Richardson (K-R. 20). Hasil perhitungan terhadap 31 butir tes yang dinyatakan valid dan memiliki daya beda cukup sampai dengan baik sekali, maka diperoleh $r_{11}=0,91$. Berdasarkan hal tersebut, maka $r_{11}>0,70$ yang berarti tes objektif tipe pilihan ganda biasa pada penelitian ini tergolong reliabel.

Instrumen yang telah diuji kualitasnya kemudian digunakan untuk mengukur kompetensi pengetahuan IPA siswa kelas V SD Gugus Pattimura Denpasar Selatan setelah diberikan perlakuan. Data hasil dari tes tersebut kemudian dianalisis menggunakan analisis statistik inferensial.Teknik analisis data yang dilakukan adalah uji hipotesis menggunakan uji t, sebelum dilakukan uji hipotesis, terlebih dahulu dilakukan uji prasyarat analisis yang meliputiuji normalitas sebaran data dan homogenitas varians.

Uji Normalitas dimaksudkan untuk mengetahui sebaran data skor kompetensi pengetahuan IPA siswa di masing-masing kelompok berdistribusi normal. Uji Normalitas sebaran data dalam penelitian ini menggunakan Chi-kuadrat $\left(X^{2}\right)$.Hasil $X^{2}$ hitung kemudian dibandingkan dengan $X_{\text {tabel}}^{2}$, pada taraf signifikasi $5 \%$ dan derajat kebebasan $(\mathrm{dk})=(\mathrm{k}-1)$. Jika $X_{\text {hitung }}^{2} \leq X_{\text {tabel, }}^{2}$, maka tidak terdapat perbedaan antara $f_{o}$ dan $f_{e}$, sehingga $\mathrm{H}_{\circ}$ diterima yang

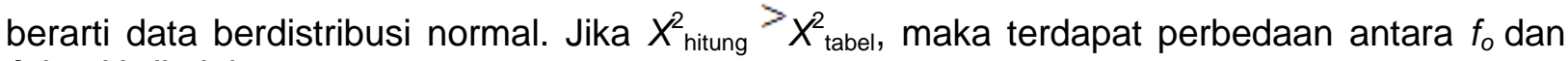
$f_{e}$ dan $\mathrm{H}_{\mathrm{o}}$ ditolak.

Uji Homogenitas dilakukan untuk menunjukkan bahwa perbedaan yang terjadi pada uji hipotesis benar-benar terjadi akibat adanya perbedaan varians antar kelompok, bukan sebagai akibat perbedaan dalam kelompok. Uji homogenitas dapat dilakukan apabila kelompok data tersebut berdistribusi normal. Uji homogenitas varians dilakukan dengan uji F. Pengujian dilakukan pada taraf signifikansi $5 \%$ dengan derajat kebebasan untuk pembilang $n_{1}-1$ dan derajat kebebasan untuk penyebut $\mathrm{n}_{2}-1$. Kriteria pengujian, jika $F_{h i t} \leq F_{\text {tabel maka sampel }}$ homogen. 
Data hasil penelitian yang telah diuji normalitas dan diuji homogenitas selanjutnya dilakukan uji hipotesis. Adapun hipotesis penelitian yang diuji yaitu $\mathrm{H}_{\circ}$ yang berbunyitidak terdapat perbedaan yang signifikan kompetensi pengetahuan IPA antara kelompok siswa yang dibelajarkan melalui model pembelajaran Course Review Horay berbantuan media Question Card dengan kelompok siswa yang dibelajarkan melalui pembelajaran konvensional pada siswa kelas V SD Gugus Pattimura Denpasar Selatan tahun pelajaran 2017/2018.

Analisis yang digunakan untuk menguji hipotesis penelitian ini adalah uji beda rerata (uji-t). Uji Hipotesis menggunakan uji-t dengan rumus polled varians.Dengan kriteria pengujian pada taraf signifikan $5 \%$ dengan $d k=n_{1}+n_{2}-2$, jika harga $t_{\text {hitung }} \leq_{t_{\text {tabel }}}$, maka $\mathrm{H}_{0}$ diterima, dan jika harga $t_{\text {hitung }}>t_{\text {tabel }}$ maka $\mathrm{H}_{\mathrm{o}}$ ditolak. Berikut rumus uji-t yang digunakan

$$
\mathrm{t}=\sqrt{\frac{\overline{\mathrm{x}}_{1}-\overline{\mathrm{x}}_{2}}{\left.\frac{\left(\mathrm{n}_{1}-1\right) \mathrm{S}_{1}^{2}+\left(\mathrm{n}_{2}-1\right.}{\mathrm{n}_{1}+\mathrm{n}_{2}-2}\right)}\left(\frac{1}{\mathrm{n}_{1}}+\frac{1}{\mathrm{n}_{2}}\right)}
$$

(Sugiyono, 2017: 197)

Keterangan:

$\mathrm{S}_{1}{ }^{2}=$ varians kelompok eksperimen

$\mathrm{S}_{2}{ }^{2}=$ varians kelompok kontrol

$\overline{\mathrm{X}}_{1} \quad=$ rerata nilai post test kelas eksperimen

$\overline{\mathrm{X}}_{2} \quad=$ rerata nilai post testkelas kontrol

$\mathrm{n}_{1} \quad=$ jumlah siswa kelas eksperimen

$\mathrm{n}_{2} \quad=$ jumlah siswa kelas kontrol

\section{Hasil Dan Pembahasan}

Hasil analisis data dari kelompok eksperimen yang dibelajarkan dengan model pembelajaran Course Review Horayberbantuan media Question Carddan kelompok kontrol yang dibelajarkan dengan pembelajaran konvensional disajikan pada tabel 1.

Tabel 1. Deskripsi Kompetensi Pengetahuan IPA Kelompok Eksperimen dan Kelompok Kontrol

\begin{tabular}{ccc}
\hline Statistik Deskriptif & Kelompok Eksperimen & Kelompok Kontrol \\
\hline N & 38 & 37 \\
Nilai Tertinggi & 94 & 87 \\
Nilai Terendah & 61 & 55 \\
Mean & 77,34 & 67,36 \\
Standar Deviasi & 7,48 & 7,59 \\
Varians & 55,92 & 57,68 \\
\hline
\end{tabular}

Data yang diperoleh kemudian dianalisis menggunakan stastistik inferensial yang terdiri dari uji prasyarat dan uji hipotesis. Uji prasyarat meliputi uji normalitas sebaran data dan uji homogenitas varians.

Hasil uji normalitas kelompok eksperimen, diperoleh $x^{2}$ hitung $=3,464$, dengan taraf signifikan $5 \%$ dan $\mathrm{dk}=\mathrm{k}-1=6-1=5$, maka diperoleh $\mathrm{X}_{\text {tabel }}^{2}=11,070$. Berdasarkan perhitungan tersebut didapatkan $X^{2}$ hitung $<X^{2}$ tabel $(3,464<11,070)$ hal tersebut menunjukkan bahwa data hasil kompetensi pengetahuan IPA di kelompok eksperimen berdistribusi normal.

Hasil uji normalitas kelompok kontrol, diperoleh $X^{2}$ hitung $=5,234$, dengan taraf signifikan $5 \%$ dan $\mathrm{dk}=\mathrm{k}-1=6-1=5$, maka diperoleh $\mathrm{X}_{\text {tabel }}^{2}=11,070$. Berdasarkan perhitungan tersebut 
didapatkan $X^{2}$ hitung $<X^{2}$ tabel $(5,234<11,070)$ hal tersebut menunjukkan bahwa data hasil kompetensi pengetahuan IPA di kelompok kontrol berdistribusi normal.

Uji homogenitas varian dilakukan dengan menggunakan uji-F. Hasil uji homogenitas, diperoleh $F_{\text {hitung }}=1,03$, dengan taraf signifikan $5 \%$ dan $\mathrm{dk}(36,37)$, maka diperoleh $\mathrm{F}_{\text {tabel }}=1,71$. Hasil uji homogenitas pada kelompok eksperimen dan kelompok kontrol menunjukkan bahwa $F_{\text {hitung }}(1,03)<F_{\text {tabel }}(1,71)$ yang berarti varians kedua kelompok tersebut homogen.

Data hasil penelitian yang telah diuji normalitas dan diuji homogenitas selanjutnya dilakukan uji hipotesis. Hipotesis penelitian yang diuji yaitu $\mathrm{H}_{0}$ yang berbunyi tidak terdapat perbedaan yang signifikan kompetensi pengetahuan IPA antara kelompok siswa yang dibelajarkan melalui model pembelajaran Course Review Horay berbantuan media Question Card dengan kelompok siswa yang dibelajarkan melalui pembelajaran konvensional pada siswa kelas V SD Gugus Pattimura Denpasar Selatan tahun pelajaran 2017/2018.

Kriteria dari pengujian yaitu $\mathrm{H}_{0}$ ditolak jika $\mathrm{t}_{\text {hitung }}>\mathrm{t}_{\text {tabel }}$, sedangkan $\mathrm{H}_{0}$ diterima jika $t_{\text {hitung }}$ $\leq_{t \text { tabel }}$, dimana $t_{\text {tabel }}$ didapatkan dari tabel distribusi $t$ pada taraf signifikasi $5 \%$ dengan derajat kebebasan $\mathrm{dk}=\left(\mathrm{n}_{1}+\mathrm{n}_{2}-2\right) \cdot$ Rekapitulasi hasil uji-t disajikan dalam Tabel 2.

Tabel 2. Rekapitulasi Hasil Analisis Uji Hipotesis Kelompok Eksperimen dan Kelompok Kontrol

\begin{tabular}{lllllll}
\hline Kelompok & $\mathrm{N}$ & $\mathrm{dk}$ & $\overline{\boldsymbol{X}}$ & $\mathrm{S}^{2}$ & $t_{\text {hitung }}$ & $\mathrm{t}_{\text {tabel }}$ \\
\hline Eksperimen & 38 & \multirow{2}{*}{73} & 77,34 & 55,92 & \multirow{2}{*}{5,905} & \multirow{2}{*}{2,000} \\
Kontrol & 37 & & 67,36 & 57,68 & & \\
\hline
\end{tabular}

Berdasarkan hasil analisis uji-t diperoleh $t_{\text {hitung }}=5,905$. Harga tersebut kemudian dibandingkan dengan harga $t_{\text {tabeldengan }} \mathrm{dk}=38+37-2=73$ dan taraf signifikansi $5 \%$ sehingga diperoleh harga $t_{\text {tabel }}=2,000$, karena $t_{\text {hitung }}>t_{\text {tabel }}$ maka $H_{0}$ ditolak. Hal ini berarti terdapat perbedaan yang signifikan kompetensi pengetahuan IPA antara kelompok siswa yang dibelajarkan melalui model pembelajaran Course Review Horay berbantuan media Question Card dengan kelompok siswa yang dibelajarkan melalui pembelajaran konvensional pada siswa kelas V SD Gugus Pattimura Denpasar Selatan tahun pelajaran 2017/2018. Sehingga dapat disimpulkan bahwa model pembelajaran Course Review Horay berbantuan Media Question Card berpengaruh terhadap kompetensi pengetahuan IPA siswa kelas V SD Gugus Pattimura Denpasar Selatan Tahun Pelajaran 2017/2018.

Berdasarkan hasil post-test yang telah diberikan kepada kedua kelompok sampel penelitian, diperoleh hasil perhitungan analisis data yang menunjukkan bahwa nilai rata-rata dari kelompok siswa yang mengikuti pembelajaran melalui model pembelajaran Course Review Horay berbantuan media Question Card memperoleh nilai rata-rata sebesar $\bar{X}=77,34$, sedangkan kelompok siswa yang mengikuti pembelajaran konvensional memperoleh nilai ratarata sebesar $\bar{X}=67,36$. Dari perolehan nilai kompetensi pengetahuan IPA pada kedua kelompok dapat diketahui bahwa kedua kelompok yang awalnya memiliki kemampuan setara, lalu setelah diberikan treatment yang berbeda, perolehan nilai kompetensi pengetahuan IPA mengalami perbedaan.

Penerapan model pembelajaran Course Review Horay berbantuan media Question Card dapat meningkatkan faktor-faktor yang mempengaruhi kompetensi pengetahuan IPA. Minat belajar siswa dapat ditingkatkan melalui kegiatan yang menyenangkan dalam proses pembelajaran, karena setiap kelompok yang berhasil menjawab pertanyaan dari Question Card dengan benar, wajib berteriak "hore!" atau menyanyikan yel-yel kelompoknya. Kegiatan ini membuat siswa merasa sedang bermain, sehingga ketika pembelajaran berlangsung pada kelas eksperimen mereka terlihat bersemangat dan senang mengikuti pembelajaran. Interaksi siswa meningkat karena pada model ini siswa diberikan kesempatan untuk berdiskusi dan berinteraksi dengan kelompoknya dalam memecahkan suatu masalah atau persoalan. Melalui diskusi kelompok, siswa berpikir bersama untuk menemukan jawaban dari kartu pertanyaan yang didapat, maka semua anggota kelompok dapat mengetahui jawaban dari kartu 
pertanyaan yang didapat. Setiap siswa akan memperoleh pengetahuan yang sama, sehingga pembelajaran menjadi efektif dan efisien.

Hasil penelitian ini mendukung penelitian-penelitian yang telah ada sebelumnya, seperti a) Penelitian yang dilakukan Marteni (2014) yang menyimpulkan bahwa model pembelajaran Course Review Horay berpengaruh terhadap hasil belajar IPA siswa kelas V SD Tahun Pelajaran 2013/2014 Di SD Gugus IV Kecamatan Buleleng, b) Penelitian yang dilakukan oleh Wirati (2014) yang menyimpulkan bahwa model pembelajaran kooperatif tipe SETS (Science Environment Technology And Society) Berbantuan Media Question Card berpengaruh terhadap hasil belajar IPS siswa kelas V SD.

Berdasarkan paparan tersebut, dapat dikatakan bahwa model pembelajaran Course Review Horay berbantuan media Question Card berpengaruh terhadap kompetensi pengetahuan IPA siswa kelas V SD Gugus Pattimura Denpasar Selatan Tahun Pelajaran 2017/2018.

\section{Simpulan dan Saran}

Berdasarkan hasil penelitian dan pembahasan dapat disimpulkan bahwa model pembelajaran Course Review Horay berbantuan media Question Card berpengaruh terhadap kompetensi pengetahuan IPA siswa kelas V SD Gugus Pattimura Denpasar Selatan tahun pelajaran 2017/2018. Hal ini dibuktikan dari hasil uji t yakni diperoleh diperoleh $t_{\text {hitung }}=5,905>$ $t_{\text {tabel }}=2,000$ maka $H_{\circ}$ ditolak. Selain itu, Rerata kompetensi pengetahuan IPA siswa kelompok eskperimen $\bar{X}_{=77,34>}>^{\bar{X}}=67,36$ rerata kompetensi pengetahuan IPA siswa kelompok kontrol.

Berdasarkan hasil penelitian ini, maka dapat disampaikan beberapa saran antara lain (1) kepada guru, Guru hendaknya dapat menambah wawasannya mengenai inovasi pembelajaran sehingga mampu menerapkan ataupun mengembangkan pembelajaran di kelas secara lebih inovatif dan bervariasi agar dapat memberikan dampak positif dalam meningkatkan kompetensi pengetahuan siswa. Salah satu model pembelajaran yang dapat diterapkan oleh guru adalah model pembelajaran Course Review Horay berbantuan media Question Card, (2) kepada kepala sekolah, Sekolah hendaknya menyediakan sarana yang maksimal untuk menunjang pembelajaran agar siswa semakin termotivasi untuk belajar dan memanfaatkan sarana tersebut untuk mengoptimalkan kompetensi siswa sehingga mutu sekolah menjadi semakin meningkat, (3) kepada peneliti bidang sejenis, Dengan dilakukannya penelitian ini, diharapkan peneliti lain melakukan penelitian lebih lanjut pada materi pembelajaran yang berbeda atau dapat pula dilakukan penelitian lebih lanjut dengan menggunakan model pembelajaran Course Review Horay berbantuan media Question Card pada sumber data/sampel yang berbeda khususnya pada muatan materi IPA sehingga hasil penelitian benar-benar dapat menggambarkan keadaan sesungguhnya yang terjadi di lapangan.

\section{Daftar Rujukan}

Agung, A.A. Gede. 2013. Buku Ajar Evaluasi Pendidikan. Singaraja: Universitas Pendidikan Ganesha.

Agung, A.A. Gede. 2014. Buku Ajar Metodologi Penelitian Pendidikan. Malang: Aditya Media Publishing.

Ardani, Ni Pt Mita. 2014. Pengaruh Model Kooperatif Tgt Berbantuan MediaQuestion Card Terhadap Hasil Belajar IPS Siswa Kelas V. Jurnal Mimbar PGSD Universitas Pendidikan Ganesha volume 2 nomor 1 tahun 2014. Tersedia pada https://ejournal.undiksha.ac.id/index.php/JJPGSD/article/download/2275/1970 (diakses tanggal 11 Januari 2018). 
Arikunto, Suharsimi. 2016. Dasar-Dasar Evaluasi Pendidikan. Jakarta: Bumi Aksara.

Arsyad, Azhar. 2011. Media Pembelajaran. Jakarta: PT Rajagrafindo Persada.

Dantes. 2012. Metode Penelitian. Yogyakarta: C.V Andi Offset.

Dantes. 2017. Desain Eksperimen dan Analisis Data. Depok: Rajawali Pers.

Daryanto dan Sudjendro, Herry. 2014. Wacana bagi Guru SD Siap Menyongsong Kurikulum 2013. Yogyakarta: Gava Media.

Japa dan Suarjana. 2015. Buku Ajar Pendidikan Matematika III. Singaraja: Universitas Pendidikan Ganesha.

Kemendikbud. 2013. Permendikbud Nomor 81A Tahun 2013. Jakarta: Kementerian Pendidikan dan Kebudayaan.

Kemendikbud. 2014. Permendikbud Nomor 57 Tahun 2014. Jakarta: Kementerian Pendidikan dan Kebudayaan.

Kemendikbud. 2014. Permendikbud Nomor 103 Tahun 2014. Jakarta: Kementerian Pendidikan dan Kebudayaan.

Kosasih. 2014. Strategi dan Pembelajaran Implementasi Kurikulum 2013. Bandung: Yrama Widya.

Kurniasih, Imas dan Berlin Sani. 2015. Ragam Pengembangan Model Pembelajaran untuk Peningkatan Profesionalitas Guru. Jakarta: Kata Pena.

Marteni, Parmiti, dkk. 2014. Pengaruh Model Pembelajaran Kooperatif Tipe Course Review Horay (CRH) Terhadap Hasil Belajar IPA Pada Siswa Kelas V SD Tahun Pelajaran 2013/2014 Di Gugus IV Kecamatan Buleleng. Jurnal Mimbar PGSD Universitas Pendidikan Ganesha, Volume 2 Nomor 1. Tersedia pada https://ejournal.undiksha.ac.id/index.php/JJPGSD/article/download/2286/1978 (diakses pada 09 Januari 2018).

Ngalimun. 2013. Strategi dan Model Pembelajaran.Yogyakarta: Aswaja Pressindo.

Rusman. 2017. Belajar dan Pembelajaran Berorientasi Standar Proses Pendidikan. Jakarta: Kencana.

Sagala, Syaiful. 2012. Konsep dan Makna Pembelajaran. Bandung: Alfabeta.

Samatowa, Usman. 2011. Pembelajaran IPA di Sekolah Dasar. Jakarta: Indeks.

Setyosari, Punaji. 2013. Metode Penelitian Pendidikan \& Pengembangan. Jakarta: Prenadamedia Group.

Shoimin, Aris. 2014. 68 Model Pembelajaran Inovatif dalam Kurikulum 2013. Yogyakarta: ArRuzz Media.

Sudijono, Anas. 2015. Pengantar Evaluasi Pendidikan. Jakarta: PT. RajaGrafindo Persada.

Sugiyono. 2017. Metode Penelitian Pendidikan. Bandung: Alfabeta. 
Sugiyono. 2017. Metode Penelitian Kuantitatif, Kualitatif, dan R\&D. Bandung: Alfabeta.

Sugiyono. 2017. Statistika Untuk Penelitian. Bandung: Alfabeta.

Sukardi. 2011. Evaluasi Pendidikan Prinsip \& Operasionalnya. Jakarta Timur: Bumi Aksara.

Susanto, Ahmad. 2013. Teori Belajar \& Pembelajarandi Sekolah Dasar. Jakarta: Kencana.

Trianto. 2012. Model Pembelajaran Terpadu. Jakarta: Bumi Aksara.

Uno, Hamzah dan Koni, Satria. 2012. Assessment Pembelajaran. Jakarta: Bumi Aksara.

Wati, Ega Rima. 2016. Ragam Media Pembelajaran. Kata Pena.

Wirati, Nyoman Ayu. 2014. Pengaruh Model Pembelajaran Kooperatif Tipe SETS (Science Environment Technology and Society) Berbantuan Media Question Card Terhadap Hasil Belajar IPS kelas V SD Gugus VI Mengwi Tahun Ajaran 2013/2014. Jurnal Mimbar PGSD Universitas Pendidikan Ganesha, Volume 2, No.1. Tersedia pada http://ejournal.undiksha.ac.id/jso/mahasiswa/index2.php (diakses tanggal 07 Januari 2018).

Yusuf, Muri. 2015. Asesmen dan Evaluasi Pendidikan. Jakarta: Prenadamedia Group. 